\title{
Care taker's compliance and Associated factors in integrated management of newborn and childhood illness with respect to antibiotics treatment in Enebise Sarmidir woreda, West Amhara, Ethiopia
}

dahibo Alemirew ( $\sim$ bscmph012@gmail.com)

East gojam Zonal health department

Taye Zeru

Amhara Public Health Institute https://orcid.org/0000-0003-0736-2955

Research Article

Keywords: Care takers, compliance, IMNCl ,Ethiopia

Posted Date: March 23rd, 2020

DOl: https://doi.org/10.21203/rs.3.rs-18103/v1

License: (9) (i) This work is licensed under a Creative Commons Attribution 4.0 International License. Read Full License 


\section{Abstract}

Background:-The Integrated Management of Newborn and Childhood Illness strategy encompasses a range of interventions to prevent and manage the major childhood illness, both in health facilities and in the home. Information on actual compliance of care takers in integrated management of newborn and childhood illness is important for program planners, policy makers, health care providers and care takers to design appropriate local and national intervention plan, to increase community participation and to improve knowledge of care takers. Based on our knowledge there are limited studies regarding to care takers compliance towards integrated management of new born and childhood illness in the study area. Therefore the result of this study used for design appropriate intervention.

Objective: - The objective of this study was to assess the care takers compliance and associated factors in integrated management of newborn and childhood illness with respect to counseling.

Methods:-Community based cross-sectional study was conducted. The study populations were all care takers of under-five children who attended integrated management of newborn and childhood illness clinic at health center. A total of 394 respondents were randomly selected by using systematic random sampling method from the seven health centers. Information on the care takers compliance was collected using structured, pre-tested questionnaire. Data entry and analysis were conducting using Statistical Package for Social Science version 16. Significance of the study was presented by using adjust odd ratio, confidence interval and $p$ value. The result was presented in texts, tables and graphs.

Result:-Three hundred seventy three care takers with under-five year children were voluntary to be interviewed, making the response rate $94.7 \%$. The findings of this study showed that $144(39 \%)$ were compliance to antibiotic treatment and $102(27.3 \%)$ were compliance to counseling. Compliance to counseling was significantly associated with age categories between 25-34 year with $(A O R=2.118,95 \% \mathrm{Cl}: 1.042,4.305)$, post-secondary education with ( $\mathrm{AOR}=2.959,95 \% \mathrm{Cl}: 1.354,6.463)$, knowledge with $(\mathrm{AOR}=2.574$, $95 \% \mathrm{Cl}: 1.482,4.469)$, trust on health workers with $(\mathrm{AOR}=2.781,95 \% \mathrm{Cl}: 1.344,5.752)$ and distance with $(\mathrm{AOR}=2.214,95 \% \mathrm{Cl}$ : $1.254,3.91)$.

Conclusion: The finding of this study revealed that the high rates of noncompliance with antibiotic treatment were identified. Therefore, implementation of integrated management of childhood illness activities at all levels should be strengthened and need to improve the social status of care takers in order to reduce child hood morbidity and mortality.

\section{Background}

Most of the children who die each year could be saved by evidence-based, cost-effective measures such as vaccines, antibiotics, micronutrient supplementation, insecticide-treated bed nets, improved family care and breastfeeding practices and oral rehydration therapy. Empowering women, removing financial and social barriers to accessing basic services, developing innovations that make the supply of critical services more available to the poor and increasing local accountability of health systems are policy interventions that have allowed health systems to improve equity and reduce mortality (1).

Major progress has been made to reduce childhood morbidity and mortality in the world, through childhood immunization, diarrhea control, acute respiratory truck infection (ARI) control, nutritional program and through implement action of other primary health care activities. In spite of such intervention under- five morbidity and mortality remain at an acceptably high rate especially in subSaharan Africa including Ethiopia (2).

IMNCl strategy helps to easily identify step by step the problem that children have when we see then their living areas and at the health post. This includes segregating simple diseases from the sever ones, urgently referring those children with severe illnesses to the next health facility, deciding what can be done for the child with simple illness, what kind of care can be given at his home and what can be done to him if his illness gets severe. In addition to this the strategy will help to focus on major disease of children, how to prevent these diseases and how the family and the community can participate and be major activities of this strategy as a tool for disease prevention, family and community participation and behavioral change, which are the principles of the strategy (3). 


\section{Methods}

Study design and period:-Community based study was conducted from December 20 to January 20/ 2014.

Study area/setting:-The study was conducted in Enebse Sarmider Woreda, East Gojjam Zone of Amahra Regional State, and Ethiopia. Enebse Sarmider Woreda is located 365 kilometers far from Addis Ababa. The woreda administratively divided in to 2 urban and 33 rural Kebles. There are seven health centers, 35 health posts and five private health facilities to give service for 154253 total population, 20453 under five years children and 31563 households. All seven health center have IMNCI trained health workers. The rural population accounts for $88.9 \%$ of the Woreda total population. The area has three geoloclimatic zones. Dega accounts for $14 \%$, Weinadega constitutes $33 \%$ and kola accounts for the remaining $53 \%$. Among under-five ten top diseases in the woreda pneumonia and diarrhea are the leading cause of morbidity and mortality (4).

Data collection instrument and collectors:-The data for this study were collected by using structured questionnaire modified from the standard WHO IMNCl exist interview, which was prepared in English and translated into Amharic language for field work purpose and back to English for checking language consistency. Types of drug prescribed were registered in field note before going to field. The data were collected by nurses. Seven data collectors were collected data from care taker in their households. Two BSC nurses were assigned as a supervisor. Data collectors and supervisors were given training for 1 day on how to use the questionnaire on interviewing, privacy, discipline and approach to respondents.

Data quality control:-A pre-test was carried out on 25 care takers at Goncha Siso Enese woreda and after pre-testing, comments were included in the questionnaire and experiences were obtained on how to proceed in the final data collection. For each data collector, one guide was assigned. The supervisors and principal investigator have closely followed and supervised the day to day data collection process and ensure completeness and consistency.

Data processing and Analysis: The questionnaires were checked for completeness and consistency by the principal investigator and supervisors prior to the analysis. Errors related to inconsistency were verified using cross tabulation and other data exploration methods. Then recoded, categorized and sorted to facilitate its analysis. The data were analyzed using SPSS version 16.0. Descriptive analysis was used to describe the number distributions of the respondents by socio-demographic characteristics and other relevant variables in the study. Furthermore, logistic regression, specifically Bivariate and multivariable analysis, were used to identify factors affecting care takers compliance on $\mathrm{IMNCl}$ antibiotic treatment and counseling. A p-value $<0.3$ was used to select candidate variables for multivariable analysis. The crude and adjusted odds ratio together with their corresponding $95 \%$ confidence intervals was computed. A P-value $<0.05$ was considered to declare a result as statistically significant in this study. The result was presented in text, tables and graphs.

\section{Results}

\section{Socio-demographic characteristics}

In this study 373 care takers with children less than five year were participate making the response rate of $94.7 \%$. Three hundred twenty seven 327 (87.7\%) care takers were female. The age of care takers ranged from 15 years to 54 years with a mean of 30.04 years and standard deviation 10.134 years. Regarding to age categories of the respondents $107(28.7 \%)$ were $15-24$ years, 134(35.9\%) were $25-34$ years, $80(21.4 \%)$ were $35-44$ years and $52(13.9 \%)$ were $45-54$ years. Two hundred ninety four (78.8\%) care takers were live in rural. Three hundred twenty $(85.8 \%)$ care takers were married.

As to the educational background 101(27.1\%) were illiterate, 57(15.3\%) were read and write, 47(12.6\%) were primary school, $78(20.9 \%)$ were secondary school and $90(24.1 \%)$ were post-secondary school. Among care takers in this study $215(57.6 \%)$ were housewife, 42(11.3\%) were Government employee, 39(10.5\%) were private/NGO employee, 28(7.5\%) were farmer, 12(3.2\%) were merchant, and the rest $37(9.9 \%)$ were others.

The monthly household income of the respondents ranges between 200 to 2245 Birr with a media of 550 Birr, standard deviation 484.082 Birr. Regarding to monthly income $99(26.5 \%)$ have monthly income less than 345 birr, 100(26.8\%) have monthly income between 346-550 birr, 83(22.3\%) have monthly income between 551-890 and the rest $91(24.4 \%)$ have monthly income above 891 birr. (Table 1) 
Two hundred sixty two (70.2\%) care takers have only one under five year child, 107(28.7\%) have two under five child and 4(1.1\%) have three under five year child. Three hundred seven (82.3\%) of children were brought to health center by their mothers. (Table 1 )

Table 1:-Socio-demographic characteristics of care takers in Enebse Sarmider woreda, in 2014. 


\begin{tabular}{|c|c|c|}
\hline Variable & Number (\%) & \\
\hline Sex & Male & $46(12.3)$ \\
\hline & Female & $327(87.7)$ \\
\hline Age & $15-24$ years & 107(28.7) \\
\hline & 25-34 years & 134(35.9) \\
\hline & $35-44$ years & $80(21.4)$ \\
\hline & $45-54$ years & $52(13.9)$ \\
\hline Residence & Urban & $79(21.2)$ \\
\hline & Rural & 294(78.8) \\
\hline Marital status & Married & $320(85.8)$ \\
\hline & Divorced & $36(9.7)$ \\
\hline & Windowed & $17(4.5)$ \\
\hline Educational & Illiterate & 101(27.1) \\
\hline & Read and write & $57(15.3)$ \\
\hline & Primary school (1-8 grade) & $47(12.6)$ \\
\hline & Secondary school & 78(20.9) \\
\hline & Post-secondary school & $90(24.1)$ \\
\hline Occupation & House wife & $215(57.6)$ \\
\hline & Government employee & $42(11.3)$ \\
\hline & Private /NGO employee & $39(10.5)$ \\
\hline & Farmer & $28(7.5)$ \\
\hline & Merchant & $12(3.2)$ \\
\hline & Others & $37(9.9)$ \\
\hline Monthly income & $<345$ birr & $99(26.5)$ \\
\hline & $346-550$ birr & $100(26.8)$ \\
\hline & $551-890$ birr & $83(22.3)$ \\
\hline & > 891 birr & $91(24.4)$ \\
\hline Number of under 5 year children & one child & 262(70.2) \\
\hline & two child & 107(28.7) \\
\hline & three child & $4(1.1)$ \\
\hline Relationship of respondent to child & Mothers & $307(82.3)$ \\
\hline & Fathers & $50(13.4)$ \\
\hline & Grandmother & $71(0.9)$ \\
\hline & Grandfather & $41(0.1)$ \\
\hline & Co mother & $20(0.5)$ \\
\hline
\end{tabular}


Table 2:-Knowledge, believe on severity of illness and number of days first noticed in health center in Enebse Sarmider Woreda in 2014.

\begin{tabular}{|c|c|c|}
\hline Variable & Categories & ( $\%)$ \\
\hline \multirow[t]{2}{*}{ Knowledge } & Knowledgeable & $169(45.3)$ \\
\hline & No knowledgeable & $45.3(54.7)$ \\
\hline \multirow[t]{2}{*}{ Believe on severity of illness } & Yes & 285(76.4) \\
\hline & No & $88(23.6)$ \\
\hline \multirow[t]{4}{*}{ Number of days sick before attending health center. } & One day & $132(35.4 \%)$ \\
\hline & Two days & $111(29.8 \%)$ \\
\hline & Three days & $80(21.4 \%)$ \\
\hline & Greater than or equal to four days & $50(15.5 \%)$ \\
\hline
\end{tabular}

Time taken to reach health center from their residence were ranged from 5 minutes to 360 minutes with median 65 minutes and standard deviation 62.376 minutes. Regarding to waiting time at health center $173(46.4 \%)$ was said that take long time. Regarding to trust on health worker $107(28.7 \%)$ were satisfied by the service delivered by health worker during visit.

Table 3:- Time taken to travel from home to health center, in Enebse Sarmider Woreda in 2014.

\begin{tabular}{|llc|}
\hline Variable & Categories & Frequency (\%) \\
\hline Total time taken & $0-60$ minutes & $176(47.2)$ \\
& $>60$ minutes & $197(52.8)$ \\
\hline Waiting time at health center & Too long time & $15(4)$ \\
& Long time & $173(46.4)$ \\
& Acceptable time & $142(38.1)$ \\
& Short time & $43(11.5)$ \\
\hline Satisfaction with service & Satisfied with the service & $107(28.7)$ \\
& Not satisfied with the service & $266(71.3)$ \\
\hline
\end{tabular}

Before attending the health centre 351 (94.1\%) had treated their child at home, of these 200 (57\%) gave homemade food or fluid, $65(18.5)$ gave holly water, $58(16.5 \%)$ gave traditional drug, $13(3.7 \%)$ give modern drug, $8(2.3 \%)$ give ORS and the rest $7(2 \%)$ give others (Figure 1).

\section{Treatment}

Oral or topical drugs were prescribed for 373 children. Three hundred sixty nine (98.9\%) children's were prescribed antibiotic. Out of 369 children treated with antibiotic Cotrimaxazole, amoxicillin, TTC eye ointment and Metrindazole were prescribed for 206(55.8\%), 83(22.5\%), 42(11.4\%) and 40(10.8\%) children respectively.

Among respondent compliance towards antibiotic treatment were $144(39 \%)$. When asked the reason not to give correct dose of antibiotic treatment, $104(46.2 \%)$ of them said that they do not know how to give the drug, $40(17.7 \%)$ of them said the child was 
improved before finishing the drug $20(9 \%)$ of them were unable to afford to buy the drug, $23(10.2 \%)$ of them said lack of trust in health worker, $20(8.9 \%)$ of them said unable to afford to buy a drug, $13(5.8 \%)$ of them said the health worker not tell me how use it, $9(4 \%)$ of them said fear of side effect, $8(3.6 \%)$ of them said shared the drug to another child and $8(3.6 \%)$ of them said the child becomes more sick(Table 4).

Table 4:- Care takers reason for not given correct dose of antibiotic treatment, in Enebse sarmider Woreda, in 2014.

\begin{tabular}{|lc|}
\hline Reason & Frequency (\%) \\
\hline Do not know how to give drug & $104(46.2)$ \\
\hline The child was improved before finishing the drug & $40(17.7)$ \\
\hline Lack of trust in health worker & $23(10.2)$ \\
\hline Unable to afford to buy a drug & $20(8.9)$ \\
\hline The health worker not tell me how use it & $13(5.8)$ \\
\hline Fear of side effect & $9(4)$ \\
\hline Shared the drug to another child & $8(3.6)$ \\
\hline The child becomes more sick & $8(3.6)$ \\
\hline Total & $225(100)$ \\
\hline
\end{tabular}

\section{Analytic Part}

Treatment

Result from the statistical analysis table 5 shows care takers with post-secondary educational status were significantly associated with compliance to antibiotic treatment having ( $\mathrm{AOR}=5.33,95 \% \mathrm{Cl}: 2.557,11.109)$, care takers with private/NGO employee were significantly associated with compliance to antibiotic treatment having ( $\mathrm{AOR}=5.936,95 \% \mathrm{Cl}$ : 1.632, 21.582), knowledgeable care takers were significantly associated with compliance to antibiotic treatment having ( $\mathrm{OOR}=1.806,95 \% \mathrm{Cl}$ : 1.096, 2.976) and those travel less than or equal to one hours from their place of residence to health center were significantly associated with compliance to antibiotic treatment having ( $\mathrm{AOR}=2.366,95 \% \mathrm{Cl}: 1.419,3.945)$.

Table 5:- Factors associated with care takers compliance towards IMNCI with respect to antibiotic treatment in Enebse sarmider Woreda in 2014. 


\begin{tabular}{|c|c|c|c|c|c|c|}
\hline \multicolumn{2}{|l|}{ Variable } & \multirow{2}{*}{$\begin{array}{l}\text { Compliance } \\
133\end{array}$} & \multirow{2}{*}{$\begin{array}{l}\text { Non } \\
\text { compliance } \\
191\end{array}$} & \multirow{2}{*}{$\begin{array}{l}\text { Crude OR/95\% Cl/ } \\
1\end{array}$} & \multirow{2}{*}{$\begin{array}{l}\text { Adjusted OR } \\
/ 95 \% \mathrm{Cl} / \\
1\end{array}$} & \multirow{2}{*}{$\begin{array}{l}\mathrm{P}- \\
\text { value }\end{array}$} \\
\hline Sex of care & Female & & & & & \\
\hline Takers & Male & 11 & 34 & $2.152(1.053,4.4)^{*}$ & $\begin{array}{l}2.24(0.849 \\
5.911)\end{array}$ & 0.103 \\
\hline \multirow{5}{*}{$\begin{array}{l}\text { Age of care } \\
\text { takers }\end{array}$} & $15-24$ years & 41 & 65 & 1 & 1 & \\
\hline & $25-34$ years & 37 & 94 & $1.602(0.929,2.765)$ & \multirow{2}{*}{$\begin{array}{l}\text { 1.479(0.786, } \\
2.738)\end{array}$} & 0.225 \\
\hline & \multirow{3}{*}{$\begin{array}{l}35-44 \text { years } \\
45-54 \text { years }\end{array}$} & 35 & 45 & $0.811(0.45,1.463)$ & & 0.465 \\
\hline & & 31 & 21 & $0.427(0.217,0.842) \star \star$ & \multirow{2}{*}{$\begin{array}{l}1.29(0.651 \\
2.559) \\
0.532(0.249 \\
1.137)\end{array}$} & 0.104 \\
\hline & & & & & & \\
\hline \multirow{6}{*}{$\begin{array}{l}\text { Educational } \\
\text { status of } \\
\text { care takers }\end{array}$} & Illiterate & 58 & 43 & 1 & 1 & \\
\hline & Read and write & 24 & 33 & $1.855(0.961,3.579)$ & \multirow{2}{*}{$\begin{array}{l}1.885(0.925 \\
3.844)\end{array}$} & 0.081 \\
\hline & Primary school & 25 & 21 & $1.133(0.562,2.285)$ & & 0.74 \\
\hline & Secondary & 20 & 56 & $3.777(1.981,7.2)^{\star \star \star}$ & $\begin{array}{l}0.867(0.373 \\
2.017)\end{array}$ & 0.609 \\
\hline & \multirow{2}{*}{$\begin{array}{l}\text { Post secondary } \\
\text { school }\end{array}$} & 17 & 72 & $\begin{array}{l}5.713(2.954 \\
11.047)^{\star \star \star}\end{array}$ & $\begin{array}{l}\text { 1.322(0.454, } \\
3.846)\end{array}$ & $\begin{array}{l}< \\
0.001\end{array}$ \\
\hline & & & & & $\begin{array}{l}5.33(2.557 \\
11.109)^{\star \star \star}\end{array}$ & \\
\hline \multirow{8}{*}{$\begin{array}{l}\text { Occupation } \\
\text { of care } \\
\text { takers }\end{array}$} & House wife & 95 & 119 & 1 & 1 & \\
\hline & Gov. employee & 8 & 33 & \multirow{2}{*}{$\begin{array}{l}3.293(1.453 \\
7.463)^{\star \star \star}\end{array}$} & \multirow{2}{*}{)$^{2.445(0.763,7.832}$} & 0.132 \\
\hline & \multirow{2}{*}{$\begin{array}{l}\text { Private } \\
\text { empl/NGO }\end{array}$} & 5 & 33 & & & 0.007 \\
\hline & & 4 & 8 & $14.017)^{\star \star \star}$ & $\begin{array}{l}5.936(1.632 \\
21.582)^{\star \star}\end{array}$ & 0.723 \\
\hline & \multirow{2}{*}{$\begin{array}{l}\text { Farmer } \\
\text { Merchant }\end{array}$} & 18 & 9 & $1.597(0.467,5.463)$ & \multirow{2}{*}{$\begin{array}{l}1.348(0.26 \\
6.996)\end{array}$} & 0.426 \\
\hline & & 14 & 23 & $0.399(0.172,0.929) *$ & & 0.107 \\
\hline & \multirow{2}{*}{ Others } & & & $1.312(0.64,2.686)$ & $\begin{array}{l}0.666(0.245 \\
1.809)\end{array}$ & \\
\hline & & & & & $\begin{array}{l}1.97(0.864 \\
4.493)\end{array}$ & \\
\hline \multirow{2}{*}{$\begin{array}{l}\text { Knowledge } \\
\text { of care } \\
\text { taker }\end{array}$} & Knowledgeable & 51 & 114 & \multirow{2}{*}{$\begin{array}{l}1.873(1.218 \\
2.879)^{\star \star \star}\end{array}$} & \multirow{2}{*}{$\begin{array}{l}1.806(1.096 \\
2.976)^{\star \star}\end{array}$} & \multirow[t]{2}{*}{0.02} \\
\hline & $\begin{array}{l}\text { No } \\
\text { knowledgeable }\end{array}$ & 93 & 111 & & & \\
\hline \multirow[t]{2}{*}{$\begin{array}{l}\text { Trust on } \\
\text { health } \\
\text { worker }\end{array}$} & $\begin{array}{l}\text { Those satisfied } \\
\text { with the service } \\
\text { delivered by } \\
\text { health worker. }\end{array}$ & 27 & 78 & $\underset{) \star \star \star \star}{2.299}(1.394,3.793$ & $\begin{array}{l}1.154(0.832 \\
2.754)\end{array}$ & 0.174 \\
\hline & $\begin{array}{l}\text { Those do not } \\
\text { satisfied with } \\
\text { the service } \\
\text { delivered by } \\
\text { health worker. }\end{array}$ & 117 & 147 & 1 & 1 & \\
\hline \multirow[t]{2}{*}{ Distance } & $\begin{array}{l}\text { Those travel } \\
\text { less than or } \\
\text { equal to one } \\
\text { hour }\end{array}$ & 43 & 130 & $\begin{array}{l}3.214(2.061 \\
5.012)^{\star \star *}\end{array}$ & $\begin{array}{l}2.366(1.419 \\
3.945) \star \star \star\end{array}$ & 0.001 \\
\hline & $\begin{array}{l}\text { Those travel } \\
\text { more than one } \\
\text { hour }\end{array}$ & 101 & 95 & 1 & 1 & \\
\hline
\end{tabular}


*= Significantly associated with compliance towards IMNCI with respect to antibiotic treatment when p value close to 0.05 .

**= Significantly associated with compliance towards $\mathrm{IMNCl}$ with respect to antibiotic treatment when $\mathrm{p}$ value close to 0.01 .

$\star * *=$ Significantly associated with compliance towards IMNCI with respect to antibiotic treatment when $\mathrm{p}$ value close to 0.001 .

$\mathrm{Cl}=$ Confidence interval and others= include students, daily labors.

\section{Discussion}

Non-compliance is defined as any deviation by a patient from health workers instructions. Non-compliance with medications is particularly important in clinical practice. This form of non-compliance has been found to be associated with treatment failure and all its consequences, namely: deterioration of patients' health, the need for additional consultations, and the use of extra drugs, additional hospital admissions and increases in direct and indirect costs of management.

Care takers compliance towards IMNCI with respect to antibiotic treatment was $38.6 \%$. Besides our study was not consistent with a study done in Hawassa in 2006 where compliance to antibiotic treatment were $21.9 \%$, which is lower than the present finding. The difference attributed could be because of difference in quality of service delivered by health workers, socio-demography and time gap.When asked the reason not to give correct dose of antibiotic treatment, majority $46.2 \%$ of them said that they do not know how to give the drug. The study which was conducted in Hawassa town indicated that reason for not given correct dose of antibiotic were majority of the respondent said do not know how to give, which is relatively similar to this findings (5).

The study conducted in Hawassa town indicate that the reasons given by care takers for giving less fluids were: did not know importance of giving more fluid $26.6 \%$, unable to suck $22.5 \%$ and child did not want to suck $21.7 \%$. This is relatively similar to the present finding (5).

Care takers compliance towards follow up was $38.6 \%$. The study conducted in Afghanistan shows that most caretakers $75 \%$ complied with referral advice. This is different from the findings of this study because compliance to follow-up higher than the present finding $38.6 \%$. The study conducted in Sudan shows that compliance with a follow-up recommendation was $44.5 \%$. This is relatively higher than the findings of this study. The study conducted in Hawassa shows that compliance to recommend follow-up visit was $19.7 \%$, which lower than the findings of this study. The study conducted in KwaZulu Natal, South Africa compliance with the primary referral was reported by less than half $(45 \%)$ of care givers which is higher than the findings of this study $(6,7,5,8)$. The difference may be due to socio-demographic difference between the study areas.

Reason for noncompliance of follow up majority $41.6 \%$ of the respondent said that the child was improved and $19 \%$ were said that I forgot follow up date. This is relatively similar to the study conducted in Hawassa health center which has $39.0 \%$ of care takers who did not attend follow up said because their child had improved, $22.9 \%$ said that they had forgotten the appointment (5).

Compliance towards IMNCl antibiotic treatment is low (38.6\%) in this study. It was affected by educational status, private/NGO employee care takers knowledge and availability of health center nearby place of residence.

This study shows that post secondary educated care takers were 5.33 times more likely significantly associated with compliance to antibiotic treatment than illiterate care takers. The study which was conducted in Hawassa town indicated that post secondary educated care takers were significantly associated with compliance to antibiotic treatment, which is similar to the present finding (5).

\section{Conclusion}

The finding of the study confirmed that high rates of noncompliance with IMNCI treatment. Compliance towards IMNCI with respect to antibiotic treatment was significantly associated with educational level, occupation, knowledge and distance. In general 
educational status, occupation, knowledge, trust on health workers, age and distance from health center were identified as factors influencing compliance towards $\mathrm{IMNCl}$ treatment and counseling.

\section{Declarations}

Declaration

Ethics approval and consent to participate

Ethical approval was obtained from Wollo university health science college ethics committee.

Consent for publication

Not applicable.

Availability of data and materials

The datasets used and/or analyzed during the current study are available from the corresponding author on reasonable request.

Competing interests

The authors declare that they have no competing interests.

Funding

The authors declare that they did not receive funding for this research.

Authors' contributions

DA conceptualized the paper. DA,TZ, performed article search, data extraction, and data analysis. DA and TZ did critical review. DA produced the first draft of the manuscript. All authors contributed to the interpretation, commented on multiple versions, and approved the final manuscript.

Acknowledgments

The authors would like to acknowledge study participants and health centers staffs.

\section{References}

(1).Child mortality. From Wikipedia, the free encyclopedia. Available from http://en-wikipedia.org /wiki/child-mortality.(Accessed 19 June 2014).

(2). Black RE, Morris SS, and Bryce J. Where and why are 10 million children dying every year? Lancet 2003; 361:2226-34.

(3).DCAHD and WHO. Integrated approach to child health in developing countries. Lancet 1999; 354:16-20.

(4). Enebse sarmider woreda health office annual report, in 2006, in Enebsia sarmider wor

(5).Demeke E. Factors influencing carer compliance in integrated management of child hood illness. 2006, Addis Ababa, Ethiopia. (unpublished) 
(6).Compliance with referrals for non-acute child health conditions: evidence from the longitudinal ASENZE study in KwaZulu Natal, South Africa. BMC Health Services Research 2014; 14:242 doi: 10.1186/1472-6963-14-242.

(7).Mohammed AS, AbdairahmanS and cousensS etal. Integrated management of childhood illnesses strategy: Compliance with referral and follow-up recommendation in Geziza state Sudan. Bulletin of the world health organization, 2003:81(10)

(8). Daniele Paranhos V, Coelho Pina J and Falleiros de Mello D. Integrated management of childhood illness with the focus on caregivers: an integrative literature review. Rev. Latino-Am. Enfermagem vol.19 no.1 Ribeirão Preto Jan./Feb. 2011 Available from http://dx.doi.org/10.1590/S0104-11692011000100027

\section{Figures}

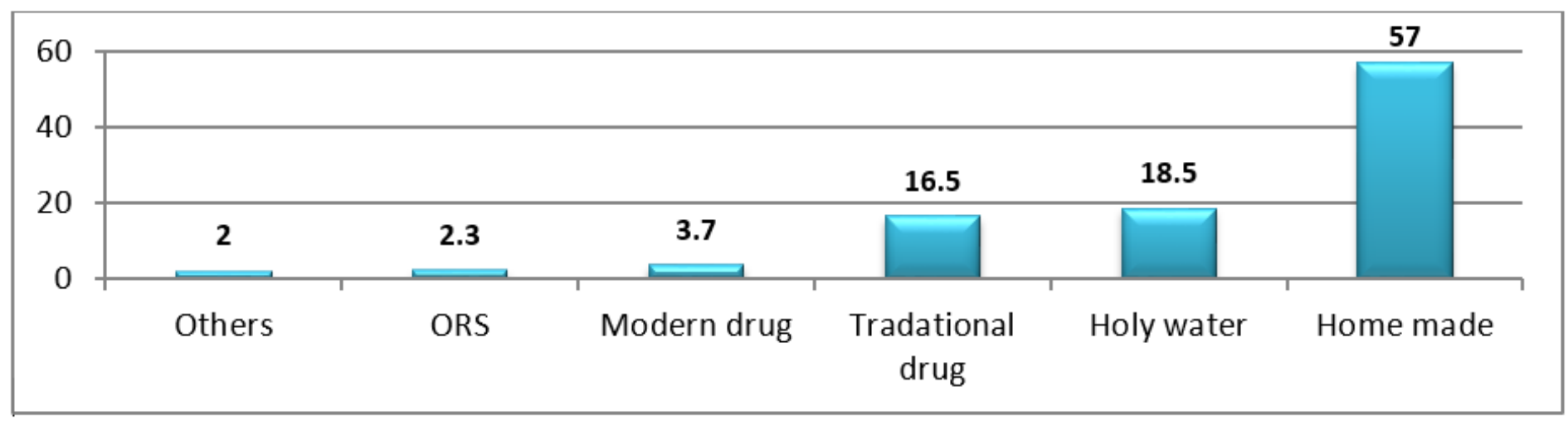

Figure 1

Type of care to sick child at home before attending health center, in Enebse sarmider Woreda in 2014 